Jurnal Abdidas Volume 2 Nomor 6 Tahun 2021 Halaman 1479- 1486

JURNAL ABDIDAS

http://abdidas.org/index.php/abdidas

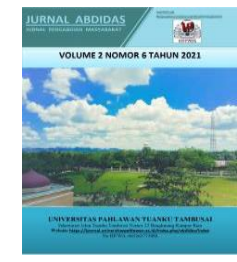

\title{
Sosialisasi Penerapan Sistem Helpdesk Ticketing Berbasis Web dalam Penanganan Keluhan Layanan di Rumah Sakit Ibu dan Anak Mutiara Bunda Padang
}

\author{
Alfauzain $^{1 凶}{ }^{\text {, Tri Wijayanto }}{ }^{2}$, Berly Nisa Srimayarti ${ }^{3}$, Dian Novita ${ }^{4}$, Zulfatly $^{5}$, \\ Piro Lismanto ${ }^{6}$, Nesia Tri Rafeta ${ }^{7}$ \\ Administrasi Rumah Sakit, STIKES Dharma Landbouw Padang, Indonesia ${ }^{1,2,3,4}$
}

D3 Rekam Medis dan Informasi Kesehatan, STIKES Dharma Landbouw Padang, Indonesia, ${ }^{5,6,7}$

E-mail :alfauzain@gmail.com ${ }^{1}$ drwide@gmail.com ${ }^{2}$ berlynisasrimayarti@gmail.com $^{3}$ diannovitasyahdi@gmail.com $^{4}$ zulfatly1712@gmail.com $^{5}$ pirolismanto172@ gmail.com 6

Nesiarafeta31@gmail.com

\begin{abstract}
Abstrak
Sistem helpdesk ticketing merupakan sistem manajemen pencatatan keluhan pasien/pelanggan terhadap layanan suatu rumah sakit menggunakan pola permintaan penomoran (request ticket) untuk memudahkan dalam penyelesaian keluhan di rumah sakit. Tujuan dilakukan pengabdian ini adalah untuk memberikan penjelasan kepada pihak terkait di rumah sakit akan pentingnya mengelola keluhan pelanggan/pasien dalam bentuk prosedur penanganan keluhan secara organisasi dan pencatatannya menggunakan sistem berupa aplikasi helpdesk ticketing sehingga terdokumentasi dengan baik tindaklanjutnya serta dapat dimonitoring oleh pimpinan atau unit kerja customer care yang diberi wewenang oleh pimpinan Rumah Sakit sehingga membantu penanganan keluhan pelanggan dengan cepat dan terorganisir dalam rangka meningkatkan pelayanan. Pengabdian ini dilakukan di RSIA Mutiara Bunda Padang dimana yang menjadi audien adalah pejabat/ staf terkait pada bagian informasi dan pelayanan pelanggan. Hasil kegiatan menunjukkan bahwa sosialisasi berjalan dengan lancar dan diharapkan peserta dapat menerima materi terutama yang disimulasikan kepada masing-masing fungsi audien. Kecepatan dalam penanganan keluhan pelanggan/pasien merupakan salah satu indikator mutu pada pelayanan kesehatan di rumah sakit.
\end{abstract}

Kata kunci: helpdesk, ticketing, WEB, PHP, MYSQL

\section{Abstract}

The helpdesk ticketing system is a management system for recording patient/customer complaints against the services of a hospital using a request ticket pattern to facilitate the resolution of complaints in hospitals. The purpose of this service is to provide an explanation to related parties in the hospital about the importance of managing customer/patient complaints in the form of organizational complaint handling procedures and recording using a system in the form of a helpdesk ticketing application so that follow-up is well documented and can be monitored by the leadership or customer work unit. care that is authorized by the hospital leadership so as to assist the handling of customer complaints quickly and organized in order to improve services. This service is carried out at RSIA Mutiara Bunda Padang where the audience is related officials/staff in the information and customer service department. The results of the activity showed that the socialization went smoothly and it was hoped that participants could receive the material, especially those that were simulated for each function of the audience. Speed in handling customer/patient complaints is one indicator of the quality of health services in hospitals.

Keywords: helpdesk, ticketing, WEB, PHP, MYSQL

Copyright (c) 2021 Alfauzain, Tri Wijayanto, Berly Nisa Srimayarti, Dian Novita, Zulfatly, Piro Lismanto, Nesia Tri Rafeta

\begin{tabular}{l}
\hline$\square$ Corresponding author \\
Address $:$ STIKES Dharma Landbouw Padang \\
Email $\quad:$ alfauzain@gmail.com \\
DOI $\quad:$ https://doi.org/10.31004/abdidas.v2i6.528
\end{tabular}

ISSN 2721-9224 (Media Cetak)

ISSN 2721- 9216 (Media Online) 
1480 Sosialisasi Penerapan Sistem Helpdesk Ticketing Berbasis Web dalam Penanganan Keluhan Layanan di Rumah Sakit Ibu dan Anak Mutiara Bunda Padang - Alfauzain, Tri Wijayanto, Berly Nisa Srimayarti, Dian Novita, Zulfatly, Piro Lismanto, Nesia Tri Rafeta

DOI: https://doi.org/10.31004/abdidas.v2i6.528

\section{PENDAHULUAN}

Rumah sakit adalah salah satu fasilitas pelayanan kesehatan, penyelenggaraan upaya kesehatan dan suatu organisasi sistem terbuka yang selalu berinteraksi dengan lingkungan untuk mencapai suatu keseimbangan yang dinamis dan mempunyai fungsi utama melayani masyarakat yang membutuhkan pelayanan kesehatan. Upaya kesehatan diselenggarakan dengan pendekatan peningkatan kesehatan (promotif), pencegahan penyakit (preventif), penyembuhan penyakit (kuratif), dan pemulihan (rehabilitatif) yang dilaksanakan secara menyeluruh, terpadu dan berkesinambungan. Semakin tinggi tingkat kecerdasan dan sosial ekonomi masyarakat, maka pengetahuan mereka terhadap penyakit, biaya, administrasi maupun upaya penyembuhan semakin baik, masyarakat akan menuntut penyelenggaraan pelayanan kesehatan yang berkualitas (UndangUndang Republik Indonesia Nomor 44, 2009).

Pengelola rumah sakit di tuntut agar dapat memberikan pelayanan kesehatan yang berkualitas, dengan memberikan kepuasan pada pasien (Ariadi, 2019). Pelayanan kesehatan yang bermutu merupakan pelayanan kesehatan yang dapat memenuhi kebutuhan yang dirasakan pasien dan dilaksanakan secara baik (Berly Nisa Srimayarti, Devid Leonard, 2021), (I, Pohan, 2007).

Kualitas pelayanan dipengaruhi oleh banyak hal yang terjadi salah satunya adalah ketidakpuasan. pelanggan/pasien sudah memahami hak-hak yang diterimanya sehingga rumah sakit harus cerdas dalam menyikapi pelayanan kepada pasien. Pasien sangat mengharapkan pelayanan yang berkualitas dari seluruh sumber daya rumah sakit, sehigga tercipta pelayanan yang bermutu. Keluhan pasien tentang terhadap antrian yang lama, respon sikap petugas yang kurang baik dan keluhan lainnya secara manual pada umumnya ditujukan ke bagian informasi maupun melalui kotak pengaduan sebagai sarana penampungan keluhan pasien (Suzuki Syofian. dkk, 2017).

Dengan adanya keluhan Pelanggan/Pasien terhadap Layanan Kesehatan sebagai bentuk keterbukaan Informasi publik yang tercantum dalam Undang-Undang Republik Indonsesia Nomor 14 Tahun 2008 Tentang Keterbukaan Informasi Publik dan Keputusan Menteri Pendayagunaan Aparatur Negara Nomor 63/Kep/M.PAN/7/2003 tentang pedoman umum penyelenggaraan pelayanan publik yang berbunyi masyarakat sebagai pengawas penyelenggaraan publik berhak melakukan laporan atau pengaduan tentang penyimpangan dan kelemahan dalam penyelenggaraan pelayanan publik (Undangundang Republik Indonesia Nomor 14, 2008), (Kementrian Pendayagunaan Aparatur Negara Nomor 63/Kep/M.PAN/7/2003, 2003)

Dalam mengatasi penyimpangan dan kelemahan penyelengggaraan pelayanan publik di bidang kesehatan khususnya rumah sakit dapat diatasi dengan penggunaan teknologi informasi sebagai alat bantu dalam pencatatan setiap keluhan ketidakpuasan pelayanan menggunakan sistem helpdesk yang berbasis komputer melalui aplikasi khusus untuk pencatatan dan monitoring tindaklanjut penanganan keluhan pasien. Dengan 
1481 Sosialisasi Penerapan Sistem Helpdesk Ticketing Berbasis Web dalam Penanganan Keluhan Layanan di Rumah Sakit Ibu dan Anak Mutiara Bunda Padang - Alfauzain, Tri Wijayanto, Berly Nisa Srimayarti, Dian Novita, Zulfatly, Piro Lismanto, Nesia Tri Rafeta

DOI: https://doi.org/10.31004/abdidas.v2i6.528

adanya aplikasi helpdesk pencatatan keluhan pasien menjadi terorganisir dengan baik dan mudah mengatur keluhan pasien yang berdatangan serta bisa dimonitor oleh pimpinan (Ryan Muhammad Bahrudin. dkk, 2019).

Helpdesk ticketing merupakan sistem tata kelola untuk membantu menangani keluhan pasien terkait dengan pertanyaan, atau komplain terhadap layanan suatu rumah sakit dengan memanfaatkan sistem penomoran (request ticket) untuk memudahkan penelusuran terhadap tindakan penyelesaian yang dikoordinasi oleh suatu bagian yang menangani keluhan. Bagian ini merupakan fungsi dalam suatu organisasi yang diberikan tugas melakukan tindak lanjut helpdesk beranggotakan beberapa orang yang menampung, mengklasifikasikan dan memberikan prioritas terhadap request ticket melalui aplikasi, serta memecahkan atau menyelesaikan masalah yang terjadi. Dalam alur proses sistem helpdesk terdapat seorang yang ditugaskan submit suatu problem/masalah kepada helpdesk, masalah yang di submit ini di sebut dengan call ticket atau trouble ticket atau ticket saja. Ticket ini akan mempunyai id yang unik/berbeda satu sama lainnya (Ryan Muhammad Bahrudin. dkk, 2019).

Penerapan sistem penanganan keluhan pada RSIA Mutiara Bunda Padang dilakukan secara manual oleh bagian informasi, dan pada data pasien rawat inap dicatat melalui pemberian formulir evaluasi pelayanan rumah sakit kepada masing-masing pasien. Kemudian berkaitan dengan hal tersebut dilakukan perancangan sistem dan penerapan model yang tepat dalam penanganan keluhan pasien di rumah sakit dengan mengintegrasikan proses penanganan keluhan pelanggan/pasien melalui dukungan sistem aplikasi helpdesk ticketing berbasis web dalam penyelesaian keluhan pelanggan.

Berdasarkan survei awal di RSIA Mutiara Bunda Padang yang menerapkan penanganan keluhan pasien diketahui bahwa sistem yang dilakukan masih secara manual oleh bagian informasi dan setiap keluhan masuk dari pelanggan belum terdokumentasi dengan baik, kemudian belum ada prosedur kerja dan aplikasi yang mendukung proses tindaklanjut keluhan dan monitoring dari pimpinan. Hal ini akan mengakibatkan penyelesaian keluhan terutama yang berkaitan dengan layanan menjadi lambat responnya dari rumah sakit, hal ini dapat berakibat pada pelayanan rumah sakit kepada pelanggan/pasien.

\section{METODE}

Pelaksanaan kegiatan sosialisasi penerapan sistem helpdesk ticketing berbasis web pada RSIA Mutiara Bunda Padang dilaksanakan kepada staf di unit kerja yang menangani informasi dan keluhan pelanggan/pasien dengan jumlah peserta sebanyak 12 orang.

Pendekatan yang dilakukan adalah berupa perancangan prosedur penanganan keluhan secara organisasi dan pengembangan serta perancangan platform sistem aplikasi helpdesk ticketing berbasis web menggunakan metode pengembangan sistem prototipe dengan bahasa pemrograman PHP dan Database MySQL. 
1482 Sosialisasi Penerapan Sistem Helpdesk Ticketing Berbasis Web dalam Penanganan Keluhan Layanan di Rumah Sakit Ibu dan Anak Mutiara Bunda Padang - Alfauzain, Tri Wijayanto, Berly Nisa Srimayarti, Dian Novita, Zulfatly, Piro Lismanto, Nesia Tri Rafeta

DOI: https://doi.org/10.31004/abdidas.v2i6.528

Sosialisasi ini dilakukan di RSIA Mutiara Bunda Padang oleh 4 orang dosen dan dibantu oleh 3 orang mahasiswa. Sosialisasi diberikan dengan bentuk penyuluhan dan simulasi ini dilakukan kepada 12 peserta di unit kerja yang menangani informasi dan keluhan pelanggan/pasien.

Sosialisasi dilakukan dengan melalui 5(lima) tahapan yaitu (1) survei sasaran penyuluhan, (2) Perancangan Prosedur Kerja dan Aplikasi Helpdesk Ticketing berbasis web (3) persiapan sarana dan prasarana penunjang, (4) pelaksanaan kegiatan inti, dan

evaluasi/monitoring. Survei sasaran bertujuan untuk mendapatkan informasi tentang lokasi dan tujuan yang belum pernah diadakan kegiatan yang serupa. Perancangan prosedur kerja merupakan kegiatan menyusun alur proses organisasi penanganan keluhan dan perancangan aplikasi berupa pembuatan sistem aplikasi dengan platform web yang sesuai kebutuhan. Persiapan sarana dan prasarana meliputi pemilihan tempat edukasi dan simulasi yang tepat dan efektif dan persiapan alatalat yang dibutuhkan berupa proyektor, laptop, server desktop dan jaringan komunikasi data.

Pada kegiatan ini, dilakukan penyuluhan akan pentingnya sistem helpdesk ticketing dalam penanganan keluhan pelanggan/pasien, sosialisasi prosedur dan aplikasi dengan cara penjelasan alur proses kerja penanganan keluhan secara organisasi dengan dukungan sistem aplikasi helpdesk ticketing berbasis web. Sosialisasi dilakukan dengan metode ceramah, dan simulasi alur proses sistem dengan melibatkan masing-masing fungsi aplikasi yaitu sebagai pelanggan/pasien, staf customer care/pimpinan dan petugas penyelesaian keluhan.

\section{HASIL DAN PEMBAHASAN}

Berdasarkan kesepakatan waktu dan lokasi kegiatan pada hari Senin, tanggal 21 November 2021, di RSIA Mutiara Bunda Padang di Ruang Kerja yang memadai untuk pelaksanaan sosialisasi dan simulasi, dengan waktu jam 14.00 WIB berakhir jam 16.00 WIB. Sebelum kegiatan dimulai sudah dilakukan persiapan lokasi dan kelengkapan peralatan serta kebutuhan yang nantinya diperlukan selama acara berlangsung.

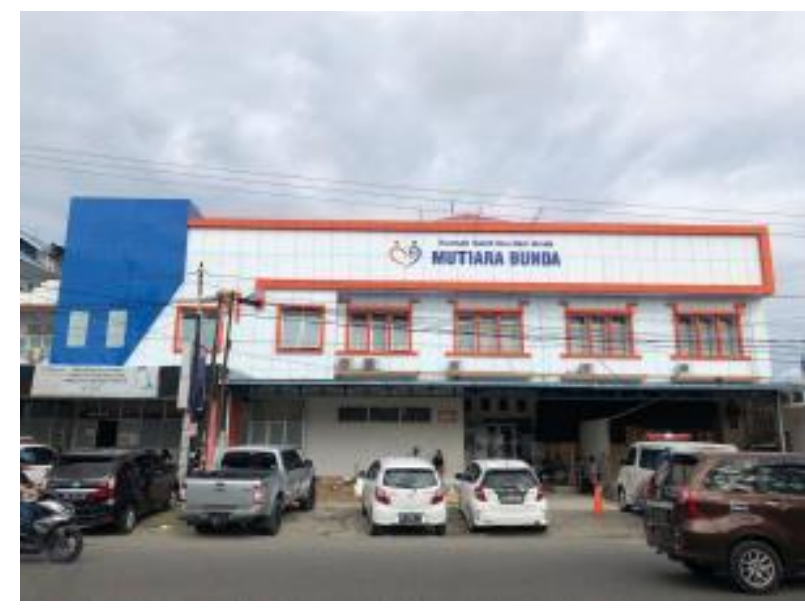

Gambar 1. Lokasi Sosialisasi di RSIA Mutiara Bunda Padang

Susunan kegiatan secara umum adalah sebagai berikut:

1. Penjelasan Alur Proses kerja Penanganan Keluhan Pasien secara organisasi 
1483 Sosialisasi Penerapan Sistem Helpdesk Ticketing Berbasis Web dalam Penanganan Keluhan Layanan di Rumah Sakit Ibu dan Anak Mutiara Bunda Padang - Alfauzain, Tri Wijayanto, Berly Nisa Srimayarti, Dian Novita, Zulfatly, Piro Lismanto, Nesia Tri Rafeta

DOI: https://doi.org/10.31004/abdidas.v2i6.528

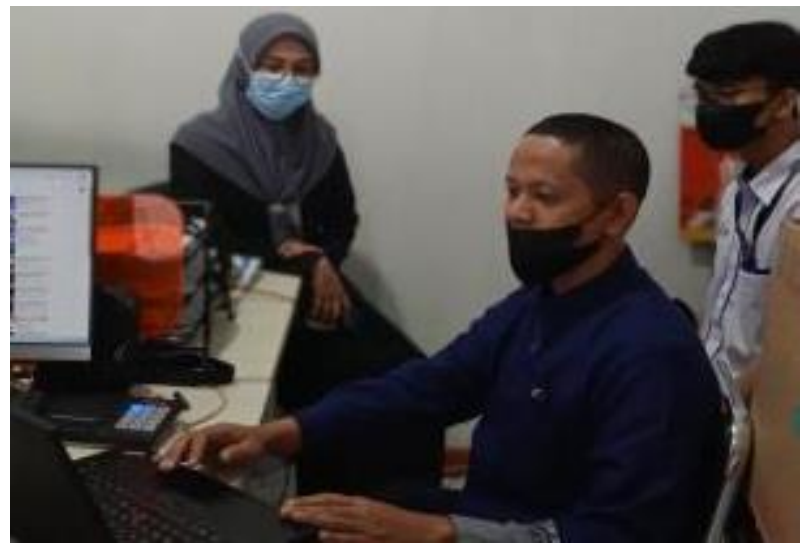

Gambar 2. Penjelasan Alur Proses Sistem Helpdesk kepada Penanggung Jawab Layanan

RSIA Mutiara Bunda memiliki sarana yang dapat dipergunakan sebagai penanganan keluhan pelanggan secara langsung maupun tidak langsung. Keluhan secara langsung dilakukan dengan bertatap muka dengan petugas atau staf yang ada dalam suatu ruangan ketika ada keluhan. Keluhan secara tidak langsung melalui sarana form keluhan, kotak saran, email maupun media sosial Facebook dan Whatsapp. Dengan adanya sarana yang tersedia memberikan kesempatan yang besar dan mudah kepada pihak terkait untuk menyampaikan keluhan.

Sebagai rancangan alur proses penanganan keluhan di RSIA Mutiara Bunda dengan unit kerja customer care yang bertanggung jawab dalam penanganan keluhan palanggan dibantu oleh petugas informasi dan operator, selanjutnya customer care melakukan disposisi keluhan kepada masing-masing penanggungjawab sesuai dengan tujuan penyelesaian keluhan (Unit Medik, Perawat, Keuangan, Logistik, dll), proses penyelesaian keluhan ini dilakukan pengawasan oleh pimpinan melalui wewenang customer care.
Alur Proses penanganan keluhan ini dilakukan melalui rancangan aplikasi helpdesk ticketing berbasis web dijelaskan secara terinci kepada penanggung jawab layanan beserta petugas informasi dan operator helpdesk.

2. Simulasi Input dan update data menggunakan masing-masing fungsi yang tersedia pada aplikasi

Sebelum dilakukan simulasi maka disusun terlebih dahulu skenario penggunaan aplikasi helpdesk ticketing sebagai berikut :

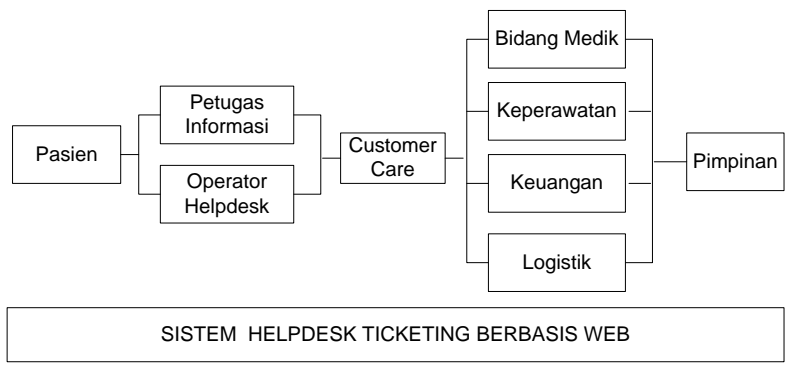

Tabel 1. Skenario Simulasi Aplikasi Helpdesk

a. Dilakukan Input data User oleh admin custumer care oleh salah satu petugas yang akan berfungsi sebagai admin untuk fungsi pelanggan, pimpinan customer care dan petugas yang menindaklanjuti layanan.

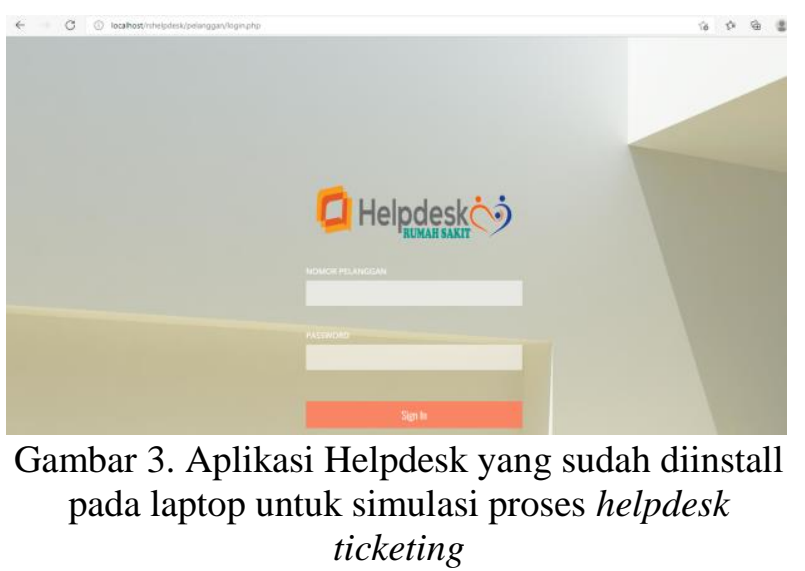


1484 Sosialisasi Penerapan Sistem Helpdesk Ticketing Berbasis Web dalam Penanganan Keluhan Layanan di Rumah Sakit Ibu dan Anak Mutiara Bunda Padang - Alfauzain, Tri Wijayanto, Berly Nisa Srimayarti, Dian Novita, Zulfatly, Piro Lismanto, Nesia Tri Rafeta

DOI: https://doi.org/10.31004/abdidas.v2i6.528

b. Untuk melakukan input data keluhan pasien maka ditunjuk 4 (empat) orang staf peserta sosialisasi yang masing-masingnya melakukan input 2 (dua) item data keluhan

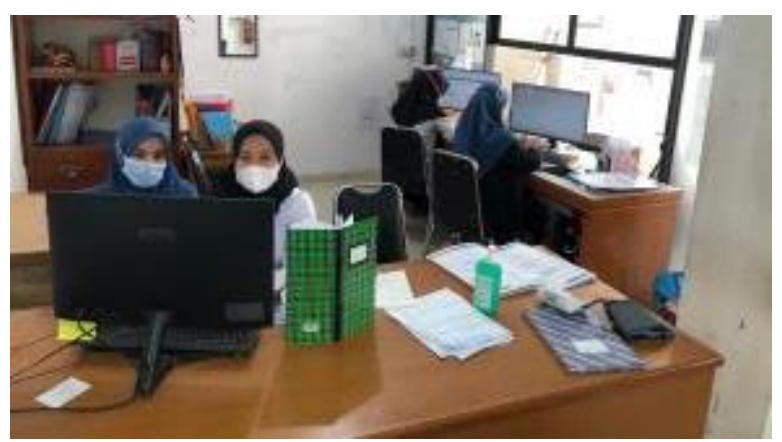

Gambar 4. Petugas yang melakukan simulasi input data keluhan pelanggan/pasien

c. Selanjutnya ticket yang sudah diinput oleh pelanggan/pasien ditugaskan oleh 2(dua) orang peserta sosialisasi yang memiliki wewenang customer care untuk menugaskan ticket kepada petugas yang bertanggungjawab sesuai jenis dan tujuan keluhan pasien

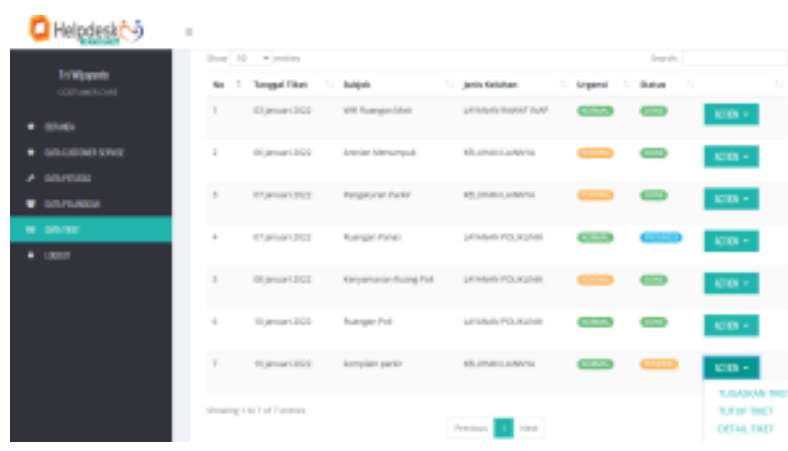

Gambar 5. Wewenang customer care untuk penugasan ticket melalui aplikasi helpdesk ticketing beserta status penyelesaian keluhan oleh petugas.

d. Sebagai petugas yang menerima penugasan ticket oleh pimpinan melakukan simulasi input detail tindaklanjut ticket dan update terhadap status ticket apabila solusi penanganan keluhan sudah selesai, simulasi ini dilakukan oleh 6 (enam) orang yang berfungsi sebagai petugas

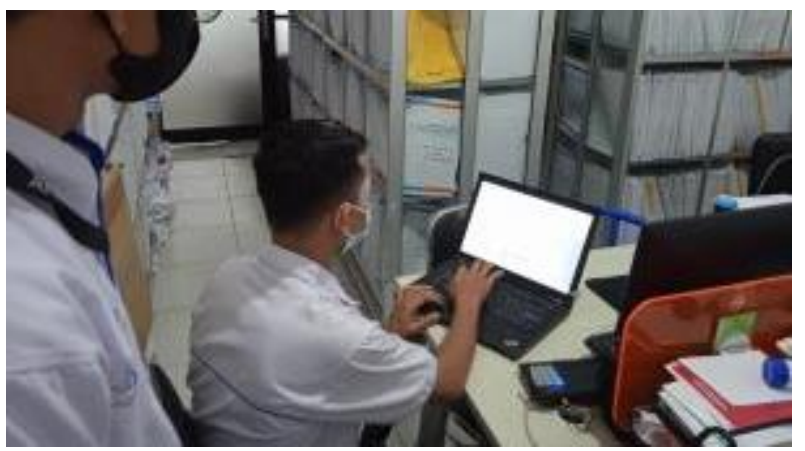

Gambar 6. Petugas yang melakukan simulasi dalam penyelesaian keluhan melalui aplikasi helpdesk ticketing

e. Masing-masing fungsi melakukan monitoring status ticket terkait melalui wewenang aplikasi yang sudah diberikan

3. Evaluasi kegiatan sosialisasi dan simulasi alur proses penanganan keluhan pelanggan melalui aplikasi helpdesk ticketing

Pada tahapan ini dilakukan evaluasi terhadap sosialisasi dan silmulasi sistem aplikasi helpdesk ticketing dalam penyelesaian penanganan keluhan pasien. Berdasarkan observasi dengan melakukan tanya jawab pengabdi dengan peserta, menunjukkan kegiatan Sosialisasi secara simulasi dalam Penerapan Sistem Helpdesk Ticketing Berbasis Web dapat dipahami dengan baik oleh peserta terutama penanggung jawab layanan Penerapan bahwa Sistem Helpdesk Ticketing Berbasis Web bermanfaat dalam penyelesaian keluhan pasien. 
1485 Sosialisasi Penerapan Sistem Helpdesk Ticketing Berbasis Web dalam Penanganan Keluhan Layanan di Rumah Sakit Ibu dan Anak Mutiara Bunda Padang - Alfauzain, Tri Wijayanto, Berly Nisa Srimayarti, Dian Novita, Zulfatly, Piro Lismanto, Nesia Tri Rafeta

DOI: https://doi.org/10.31004/abdidas.v2i6.528

Kemampuan dan cara penyajian sosialisasi dengan kegiatan simulasi sangat menarik dan interaktif sehingga memudahkan staf terkait untuk memahami isi yang disampaikan sehingga dapat diusulkan untuk penerapannya secara langsung di rumah sakit.

\section{UCAPAN TERIMA KASIH}

Pengabdi mengucapkan terima kasih kepada STIKES Dharma Landbouw Padang beserta tim penulis di Prodi S1 Administrasi Rumah Sakit dan Prodi DIII Rekam Medis dan Informasi Kesehatan atas dukungan yang diberikan, serta Pimpinan dan Staf Rumah Sakit Mutiara Bunda yang memberikan kesempatan untuk melakukan sosialisasi dan simulasi.

\section{SIMPULAN}

Berdasarkan hasil pelaksanaan pengabdian kepada masyarakat dengan tema "Sosialisasi Penerapan Sistem Helpdesk Ticketing Berbasis Web dalam Penanganan Keluhan Layanan Pasien/Pelanggan di Rumah Sakit Ibu dan Anak Mutiara Bunda Padang", disimpulkan sebagai berikut ini :

1. Kegiatan Sosialisasi Penerapan Sistem Helpdesk Ticketing Berbasis Web dalam Penanganan Keluhan terhadap Layanan Pasien/Pelanggan di Rumah Sakit Ibu dan Anak Mutiara Bunda Padang dengan simulasinya berjalan dengan lancar.

2. Dengan dilakukannya penjelasan alur proses kegiatan dan kegiatan simulasi menggunakan aplikasi yang sudah diinstall pada laptop/komputer menambah semangat peserta dalam mengikuti kegiatan

3. Keberhasilan sosialisasi dipengaruhi oleh penyaji materi, fungsi aplikasi helpdesk ticketing yang sederhana dan menarik serta skenario simulasi yang singkat dan tepat sasaran

\section{DAFTAR PUSTAKA}

Ariadi, H. (2019). Komplain Pasien di Pelayanan Rumah Sakit (Patient Complaints In Hospital Services). Caring Nursing Journal, 3(1), 7 13. Retrieved from https://journal.umbjm.ac.id/index.php/caringnursing/article/view/275

Berly Nisa Srimayarti, Devid Leonard, D. Z. Y. (2021). Determinants of Health Service Efficiency in Hospi-tal: A Systematic Review. International Journal of Engineering, Science and Information Technology, 1(3), 87-91. https://doi.org/10.52088/ijesty.v1i3.115

I, P. (2007). Jaminan Mutu Layanan Kesehatan Dasar-Dasar Pengertian dan Penerapan. Jakarta: EGC.

Kementrian Pendayagunaan Aparatur Negara Nomor 63/Kep/M.PAN/7/2003. Pedoman Umum Penyelenggaraan Pelayanan Publik (2003). Jakarta.

Ryan Muhammad Bahrudin. dkk. (2019). Penerapan Helpdesk Ticketing System Dalam Penanganan Keluhan Penggunaan Sistem Informasi Berbasis Web Tanggerang. JUTIS, Universitas Islam Syekh-Yusuf, 7(1), 71-82.

Suzuki Syofian. dkk. (2017). Aplikasi Helpdesk Mendukung Sistem Ticketing. Jurnal Manajemen Kesehatan Masyarakat. Jakarta. Universitas Respati Indonesia(Urindo)., 3(1), 1-7. Retrieved from http://ejournal.urindo.ac.id/index.php/TI/artic le/view/264

Undang-undang Republik Indonesia Nomor 14. 
1486 Sosialisasi Penerapan Sistem Helpdesk Ticketing Berbasis Web dalam Penanganan Keluhan Layanan di Rumah Sakit Ibu dan Anak Mutiara Bunda Padang - Alfauzain, Tri Wijayanto, Berly Nisa Srimayarti, Dian Novita, Zulfatly, Piro Lismanto, Nesia Tri Rafeta DOI: https://doi.org/10.31004/abdidas.v2i6.528

Keterbukaan Informasi Publik (2008).

Jakarta.

Undang-Undang Republik Indonesia Nomor 44. Rumah Sakit, 4 (2009). Indonesia. Retrieved from

https://peraturan.bpk.go.id/Home/Details/387 89/uu-no-44-tahun-2009. 